\title{
DYNAMICAL DOWNSCALING LUARAN GLOBAL CLIMATE MODEL (GCM) MENGGUNAKAN MODEL REGCM3 UNTUK PROYEKSI CURAH HUJAN DI KABUPATEN INDRAMAYU
}

\section{DYNAMICAL DOWNSCALING OF GLOBAL CLIMATE MODEL (GCM) OUTPUT BY USING REGCM3 MODEL FOR RAINFALL PROJECTION IN INDRAMAYU DISTRICT}

\author{
Syamsu Dwi Jadmiko ${ }^{{ }^{*}}$ dan Akhmad Faqih ${ }^{1,2}$ \\ ${ }^{1}$ Centre for Climate Risk Management in Southeast Asia and Pacific (CCROM-SEAP) IPB \\ ${ }^{2}$ Departemen Geofisika dan Meteorologi, \\ Gedung FMIPA, Jl Meranti Wing 19 Lv. 4 Kampus IPB Darmaga, Bogor 16680 \\ * Corresponding author, email: djsyamsoe@gmail.com
}

Penyerahan Naskah: 5 Februari 2013

Diterima untuk diterbitkan: 10 Januari 2014

\begin{abstract}
Future rainfall projection can be predicted by using Global Climate Model (GCM). In spite of low resolution, we are not able specifically to describe a local or regional information. Therefore, we applied downscaling technique of GCM output using Regional Climate Model (RCM). In this case, Regional Climate Model version 3 (RegCM3) is used to accomplish this purpose. RegCM3 is regional climate model which atmospheric properties are calculated by solving equations of motion and thermodynamics. Thus, RegCM3 is also called as dynamic downscaling model. RegCM3 has reliable capability to evaluate local or regional climate in high spatial resolution up to $10 \times 10 \mathrm{~km}$. In this study, dynamically downscaling techniques was applied to produce high spatial resolution $(20 \times 20 \mathrm{~km})$ from GCM EH5OM output which commonly has rough spatial resolution $\left(1.875^{\circ} \times 1.875^{\circ}\right)$. Simulation show that future rainfall in Indramayu is relatively decreased compared to the baseline condition. Decreased rainfall generally occurs during the dry season (July-June-August/JJA) in a range 10-20\%. Study of extreme daily rainfall indicates that there is no significant increase or decrease value.
\end{abstract}

Keywords: downscaling, dynamic down-scaling, future rainfall, RegCM3

Sitasi: Jadmiko S.D. dan Faqih A. 2014. Dynamical downscaling luaran Global Climate Model (GCM) menggunakan model RegCM3 untuk proyeksi curah hujan di Kabupaten Indramayu. J Agromet Indonesia. 28(1):9-16.

\section{PENDAHULUAN}

Curah hujan merupakan unsur iklim yang sangat penting di Indonesia terutama dalam bidang pertanian. Curah hujan memiliki keragaman cukup tinggi menurut ruang dan waktu. Di daerah tropis seperti Indonesia, curah hujan secara umum bervariasi dari tahun ke tahun. Besar curah hujan juga bervariasi menurut ketinggian tempat. Daerah dataran tinggi secara umum memiliki curah hujan yang lebih tinggi dibandingkan dengan daerah dataran rendah yang berada di sekitar pantai (Asdak, 1995).

Informasi curah hujan secara lokal/regional di suatu wilayah menjadi sangat penting karena saat ini tidak semua wilayah di Indonesia memiliki stasiun hujan yang memadai. Oleh karena itu, dikembang- kan metode-metode pendugaan ataupun prediksi curah hujan secara lokal/regional berdasarkan informasi secara global seperti data luaran Global Climate Model (GCM). Downscaling merupakan salah satu teknik regionalisasi dari data global untuk mendapatkan hasil yang lebih baik secara lokal/regional. Wilby dan Wigley (1997) menyatakan downscaling merupakan cara interpolasi peubah skala global dengan peubah skala lokal/ regional. Saat ini teknik downscaling banyak digunakan untuk memperoleh informasi iklim yang lebih detail secara lokal/regional dari informasi skala global. Salah satu teknik downscaling yang berkembang saat ini adalah dynamical downscaling dengan menggunakan model-model dinamik sebagai proses simulasinya. 
Regional Climate Model version 3 (RegCM3) merupakan model iklim regional yang banyak digunakan untuk analisis iklim secara regional, dan merupakan salah satu model dynamical downscaling. Penggunaan model RegCM3 memungkinkan untuk melakukan downscaling data curah hujan berdasarkan data model iklim global. RegCM3 memiliki kemampuan untuk mensimulasikan kondisi iklim di suatu wilayah secara regional/lokal dengan resolusi tinggi.

Kejadian perubahan iklim yang terjadi saat ini telah menyebabkan pergeseran musim dan pola curah hujan. Beberapa kajian perubahan curah hujan di Indonesia akibat perubahan iklim mengindikasikan bahwa selama abad 20 kondisi curah hujan mengalami peningkatan di satu wilayah sedangkan wilayah lain terjadi penurunan curah hujan sebesar 2-3\% (Hulme dan Sheard, 1999). Secara regional, hasil proyeksi curah hujan di beberapa wilayah Indonesia berdasarkan model mengindikasikan terdapat penurunan curah hujan di sebagian wilayah sedangkan di wilayah lain mengalami peningkatan (Sarah dan Tohari, 2009; Susandi et al., 2008).

Penelitian ini bertujuan untuk menganalisa kondisi curah hujan masa depan dan kejadian hujan ekstrim (extreme rainfall) di Kabupaten Indramayu berdasarkan hasil downscaling data GCM. Dengan informasi tersebut, diharapkan dapat menjadi landasan ilmiah dalam pemilihan langkah adaptasi sehingga dampak yang mungkin ditimbulkan dapat diminimalkan.

\section{METODE PENELITIAN}

\section{Deskripsi Wilayah Kajian}

Indramayu merupakan salah satu kabupaten di Jawa Barat yang menjadi sentra produksi padi di Pulau Jawa. Indramayu memiliki luas wilayah sekitar 204.011 Ha dengan luas sawah sebesar 118.513 Ha dan sebagian besar wilayah berada pada ketinggian 0-3 mdpl. Kabupaten Indramayu terletak pada $107^{\circ} 52^{\prime}-108^{\circ} 36^{\prime}$ BT dan $6^{\circ} 15^{\prime}-6^{\circ} 40^{\prime}$ LS. Wilayahnya berbatasan dengan Laut Jawa di sebelah utara dan timur, Kabupaten Subang di sebelah barat, Kabupaten Sumedang, Majalengka, dan Cirebon di sebelah selatan.

Iklim di Kabupaten Indramayu termasuk ke dalam tipe iklim D (iklim sedang) berdasarkan klasifikasi iklim Schmidt-Ferguson. Suhu udara ratarata berkisar antara $26^{\circ} \mathrm{C}$ sampai $27,6^{\circ} \mathrm{C}$. Suhu udara tertinggi terletak pada wilayah utara Indramayu yang merupakan wilayah pesisir pantai sedangkan suhu terendah berada pada wilayah selatan yang berbatasan dengan Kabupaten Sumedang. Curah hujan rata-rata tahunan berkisar antara $934 \mathrm{~mm}$ sampai $1891 \mathrm{~mm}$ dengan jumlah hari hujan sebanyak 75 hari. Curah hujan di Indramayu secara umum menyebar merata di bagian tengah wilayah Indramayu. Curah hujan terbesar berada di bagian selatan yang berbatasan dengan Kabupaten Sumedang seperti pada Kecamatan Haurgeulis dan Cikedung, sedangkan di daerah sekitar pantai bagian utara memiliki curah hujan yang lebih rendah seperti pada Kecamatan Anjatan, Kandanhaur, dan Bongas.

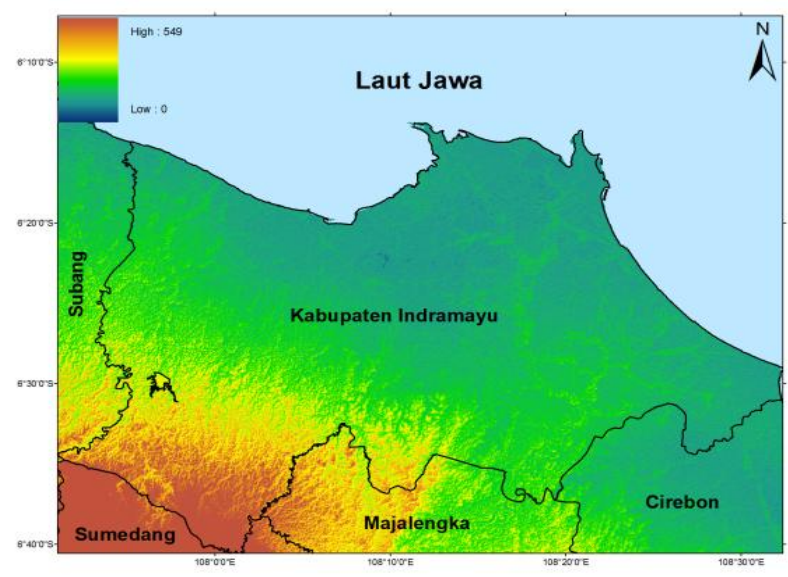

Gambar 1. Peta dan topografi Kabupaten Indramayu.

\section{Data}

Data dalam penelitian ini meliputi data observasi dari stasiun yang ada di Kabupaten Indramayu dan data model GCM EH5OM. Di Indramayu terdapat 36 stasiun hujan yang tersebar di seluruh wilayah. Namun ketersedian periode data dari masing-masing stasiun tidak sama sehingga dilakukan pemilihan stasiun yang memiliki periode data yang sama. Dari proses pemilihan diperoleh 26 stasiun hujan yang memiliki periode data yang sama yaitu dari tahun 1980 sampai tahun 1999. Data curah hujan per-stasiun hujan tersebut kemudian dibuat curah hujan wilayah yang mewakili curah hujan wilayah Indramayu. Curah hujan wilayah dihitung menggunakan metode Polygon Thiessen.

Data model GCM EH5OM merupakan data global dengan resolusi spasial $1,875^{\circ} \times 1,875^{\circ}$ dan resolusi temporal 3 jam-an. Data ini digunakan sebagai initial and boundary condition (ICBC) untuk menjalankan model RegCM3. Proyeksi curah hujan masa depan menggunakan data skenario emisi gas rumah kaca SRES A1B yang menggambarkan keseimbangan penggunaan energi dari bahan bakar fosil dan non-fosil.

\section{Model dan Simulasi}

Dynamical downscaling merupakan metode regionalisasi data luaran Global Climate Model (GCM) menggunakan Regional Climate Model (RCM) untuk mendapatkan informasi yang lebih detail (Hay dan Clark, 2003). Hal tersebut didasarkan pada domain area luaran masing-masing model dimana GCM umumnya memiliki domain 
area maksimal hingga $100 \times 100 \mathrm{~km}$ sedangkan RCM memiliki domain area lebih kecil hingga $10 \times$ $10 \mathrm{~km}$ (Giorgi et al. 2001). Dynamical downscaling membutuhkan kondisi batas (boundary condition) dari model GCM untuk digunakan dalam simulasi RCM dimana karakteristik atmosfer dihitung menggunakan persamaan gerak dan termodinamika (Spak et al., 2007).

Dynamical downscaling pada penelitian ini menggunakan Regional Climate Model version 3 (RegCM3). RegCM3 merupakan salah satu model iklim regional (Regional Climate Model/RCM) yang dikembangkan oleh International Centre for Theoretical Physics (ICTP), Italy. RegCM3 telah banyak digunakan dalam studi berbasis analisis iklim dalam skala regional/lokal dengan resolusi tinggi. Di beberapa belahan dunia seperti Eropa, Amerika, dan Afrika, studi analisis iklim menggunakan RegCM3 dirasa memberikan hasil yang lebih baik dibandingkan dengan menggunakan model GCM. Selain itu, RegCM3 memberikan hasil yang konsisten di setiap simulasi yang dilakukan (Park et al., 2008).

Model permukaan daratan yang digunakan dalam analisis adalah Biosphere Atmosphere Transfer Scheme (BATS; Dickinson et al., 1993) dengan skema lapisan perbatas (Planetary Boundary Layer Scheme) berupa formulasi non-lokal Holtslag (Holtslag et al., 1990). Skema konvektif untuk hujan menggunakan skema konvektif MIT-Emanuel. Skema konvektif MIT-Emanuel merupakan model ideal dari gerakan udara updraft dan downdraft dengan metode buoyancy sorting. Hal tersebut menentukan tingkat penambahan dan pengurangan parsel udara pada level tertentu untuk mendapatkan potensi uap air yang cukup (Emanuel dan ZivkovicRothman, 1999; Emanuel, 1991).

Proyeksi menggunakan skenario perubahan emisi SRES A1B dengan asumsi adanya keseimbangan penggunaan bahan bakar fosil dan non-fosil di masa mendatang (IPCC, 2000). Skenario SRES A1B lebih difokuskan pada pertumbuhan sektor ekonomi yang cepat secara global. Hal tersebut secara tidak langsung menyebabkan konsumsi manusia akan bahan bakar fosil yang merupakan salah satu penyumbang emisi gas rumah kaca (GRK) semakin besar. Berdasarkan skenario ini, perkiraan peningkatan suhu udara pada tahun 2100 berkisar antara $1,4-6,4^{\circ} \mathrm{C}$ (Kurniawan et al., 2009). Periode proyeksi dibagi menjadi 20 tahunan (periode tahun 2021-2040, tahun 20412060, dan tahun 2061-2080) dengan baseline periode tahun 1980-1999. Skala spasial yang digunakan dalam menjalankan model RegCM3 adalah $20 \times 20 \mathrm{~km}$.

\section{Validasi, Koreksi dan Analisis Keluaran Model $\mathrm{RegCM3}$}

Keluaran model RegCM3 secara umum memberikan hasil yang lebih besar dibandingkan dengan data observasi (overestimate). Namun demikian pola curah hujan hasil model dengan data observasi memiliki keeratan yang cukup baik. Keeratan tersebut dilihat dari nilai koefisien korelasi (r) dan root mean square error (RMSE). Nilai koefisien korelasi dihitung berdasarkan persamaan berikut:

$$
r=\frac{\sum_{i=1}^{n}\left(x_{\mathrm{mod}}-x_{\mathrm{mod}}^{\prime}\right)\left(x_{o b s}-x_{o b s}^{\prime}\right)}{\sqrt{\left(\sum_{i=1}^{n}\left(x_{\mathrm{mod}}-x_{\mathrm{mod}}^{\prime}\right)^{2} \sum_{i=1}^{n}\left(x_{o b s}-x_{o b s}^{\prime}\right)^{2}\right.}}
$$

Sedangkan nilai RMSE dihitung menggunakan persamaan berikut:

$$
R M S E=\sqrt{\frac{\sum_{i=1}^{n}\left(x_{\mathrm{mod}}-x_{o b s}\right)^{2}}{n}}
$$

dengan $n$ adalah banyak data yang digunakan, $x_{o b s}$ adalah CH Observasi, dan $x_{\text {mod }}$ adalah CH Model.

Dari hasil analisis data diperoleh nilai koefisien korelasi (r) sebesar 0,56 dan nilai RMSE sebesar 133. Gambar 2 menunjukkan pola curah hujan hasil model sesuai skema terpilih dengan curah hujan observasi.

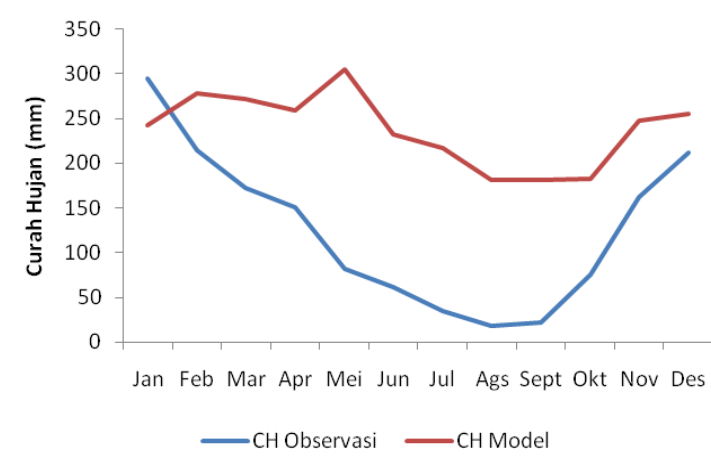

Gambar 2. Perbandingan pola curah hujan model terpilih dan curah hujan observasi.

Dari Gambar 2 dapat dilihat bahwa secara umum nilai curah hujan model memberikan nilai yang lebih besar dibandingkan dengan nilai curah hujan observasi (overestimate). Hanya pada bulan Januari yang menunjukkan nilai curah hujan model yang kurang dari nilai curah hujan observasi (underestimate). Dengan adanya nilai overestimate dan underestimate, maka sebelum melakukan proyeksi terlebih dahulu dilakukan koreksi terhadap nilai curah hujan model. Hal tersebut dilakukan untuk mengetahui seberapa besar nilai yang harus dikurangkan atau ditambahkan terhadap curah hujan model.

Faktor koreksi dihitung berdasarkan perbedaan antara data observasi dan data model. Periode data 
observasi dan data model untuk penentuan faktor koreksi harus sama yaitu periode tahun 1980-1999. Persamaan yang digunakan untuk menghitung besarnya faktor koreksi (\%) adalah sebagai berikut (Faqih et al., 2011):

$$
\text { Faktorkoreksi }=\frac{\text { Data model }- \text { DataObs }}{\text { Data model }} \times 100
$$

Faktor koreksi yang diperoleh selanjutnya digunakan untuk menentukan curah hujan terkoreksi dari model (baseline dan proyeksi). Curah hujan terkoreksi dihitung berdasarkan persamaan berikut:

$\mathrm{CH}$ terkoreks $=\mathrm{CH}$ model $\times$ Faktorkoreksi

Untuk menentukan curah hujan masa depan maka dilakukan perbandingan antara data proyeksi dan baseline dari model. Nilai perubahan curah hujan (\%) antara kondisi proyeksi dan baseline dihitung melalui persamaan berikut:

$$
\text { PerubahanCH }=\frac{\text { proyeksi- baseline }}{\text { baseline }} \times 100
$$

Nilai perubahan curah hujan (\%) yang diperoleh dengan menggunakan persamaan di atas antara baseline dan proyeksi, digunakan untuk menghitung curah hujan masa depan berdasarkan persamaan berikut:

$$
\mathrm{CH} \text { proyeksi }=\text { DataObs }+\left(\text { DataObs } \frac{\text { perubahanCH }}{100}\right)
$$

Analisis curah hujan ekstrim dilakukan menggunakan analisis distribusi peluang curah hujan maksimum harian. Analisis peluang hujan ekstrim dilakukan pada curah hujan harian pada bulan Desember-Februari, dimana pada bulan tersebut merupakan bulan terbasah sepanjang tahun di daerah Indramayu. Besarnya peluang curah hujan ekstrim dapat dilakukan dengan pendekatan distribusi frekuensi. Distribusi frekuensi merupakan model perhitungan histogram dengan menggunakan pengelompokan data. Distribusi frekuensi yang digunakan dalam analisis ini adalah distribusi gamma. Hujan ekstrim dibagi menjadi dua kategori yaitu ekstrim kering dan ekstrim basah. Nilai peluang kejadian ekstrim kering adalah besarnya peluang hujan yang nilainya kurang dari kuartil 1 (Q1) dan peluang kejadian ekstrim basah adalah besarnya peluang hujan yang melebihi kuartil 3 (Q3). Namun demikian, dalam tulisan ini hanya akan dibahas mengenai curah hujan ekstrim basah.

\section{HASIL DAN PEMBAHASAN}

\section{Proyeksi Curah Hujan}

Perubahan iklim terjadi akibat peningkatan emisi gas rumah kaca (GRK) di atmosfer. Secara alami, GRK dapat menahan radiasi matahari langsung sehingga bumi terasa hangat dan dapat dihuni oleh manusia. Namun, dengan akumulasi emisi GRK yang semakin tinggi menyebabkan suhu udara global di permukaan bumi semakin meningkat dan berdampak pada kehidupan yang ada di dalamnya. Perubahan iklim dapat mempengaruhi kondisi iklim dan lingkungan. Beberapa dampak yang mungkin dapat timbul akibat perubahan iklim adalah (1) pergeseran musim dan pola curah hujan, (2) meningkatnya suhu yang menyebabkan kebakaran hutan, (3) kenaikan muka air laut, (4) menurunkan produktivitas pertanian dan (5) meningkatnya frekuensi kejadian ekstrim (Susandi et al., 2008).

Hasil simulasi perubahan curah hujan menggunakan model RegCM3 mengindikasikan bahwa kondisi curah hujan di Kabupaten Indramayu di masa mendatang cenderung akan mengalami penurunan. Pada periode proyeksi tahun 2021-2040, curah hujan akan mengalami penurunan yang berkisar antara 9-12,6\% dari curah hujan periode tahun 1980-1999. Penurunan curah hujan terbesar terjadi pada periode tahun 2061-2080 yaitu mencapai $17,5 \%$ yang berada pada bagian timur hingga selatan Indramayu. Perubahan curah hujan pada periode tahun 2041-2060 sedikit berbeda dengan periode lainnya. Pada periode ini kondisi curah hujan cenderung mengalami peningkatan. Peningkatan curah hujan secara umum terjadi di bagian utara Indramayu, sedangkan pada bagian selatan cenderung mengalami penurunan curah hujan. Secara spasial kondisi tersebut dapat dilihat pada Gambar 3. Secara musiman perubahan curah hujan pada musim penghujan cenderung mengalami peningkatan, sedangkan pada musim kemarau cenderung akan mengalami penurunan. Gambar 4 menunjukan rata-rata curah hujan bulanan di Kabupaten Indramayu periode baseline dan periode proyeksi. Pola curah hujan di masa mendatang masih berupa pola curah hujan monsunal. Puncak curah hujan terjadi pada bulan Januari dan curah hujan terendah pada bulan Agustus/September. Curah hujan bulan Januari menunjukan peningkatan yang cukup signifikan.

Perubahan curah hujan di masa mendatang dapat berpengaruh pada berbagai sektor. Pada wilayah pertanian, kondisi ini tentu akan menyebabkan perubahan pola tanam. Selain itu, dengan berkurangnya musim penghujan akan menyebabkan lama musim tanam juga akan berubah. Hasil analisa yang dilakukan Alfyanti (2011) menyatakan bahwa dengan perubahan curah hujan di masa yang akan datang, awal musim tanam rata-rata akan mengalami kemunduran 1 hingga 2 dasarian. Selain itu waktu tanam padi juga hanya bisa dilakukan satu kali dalam setahun. 

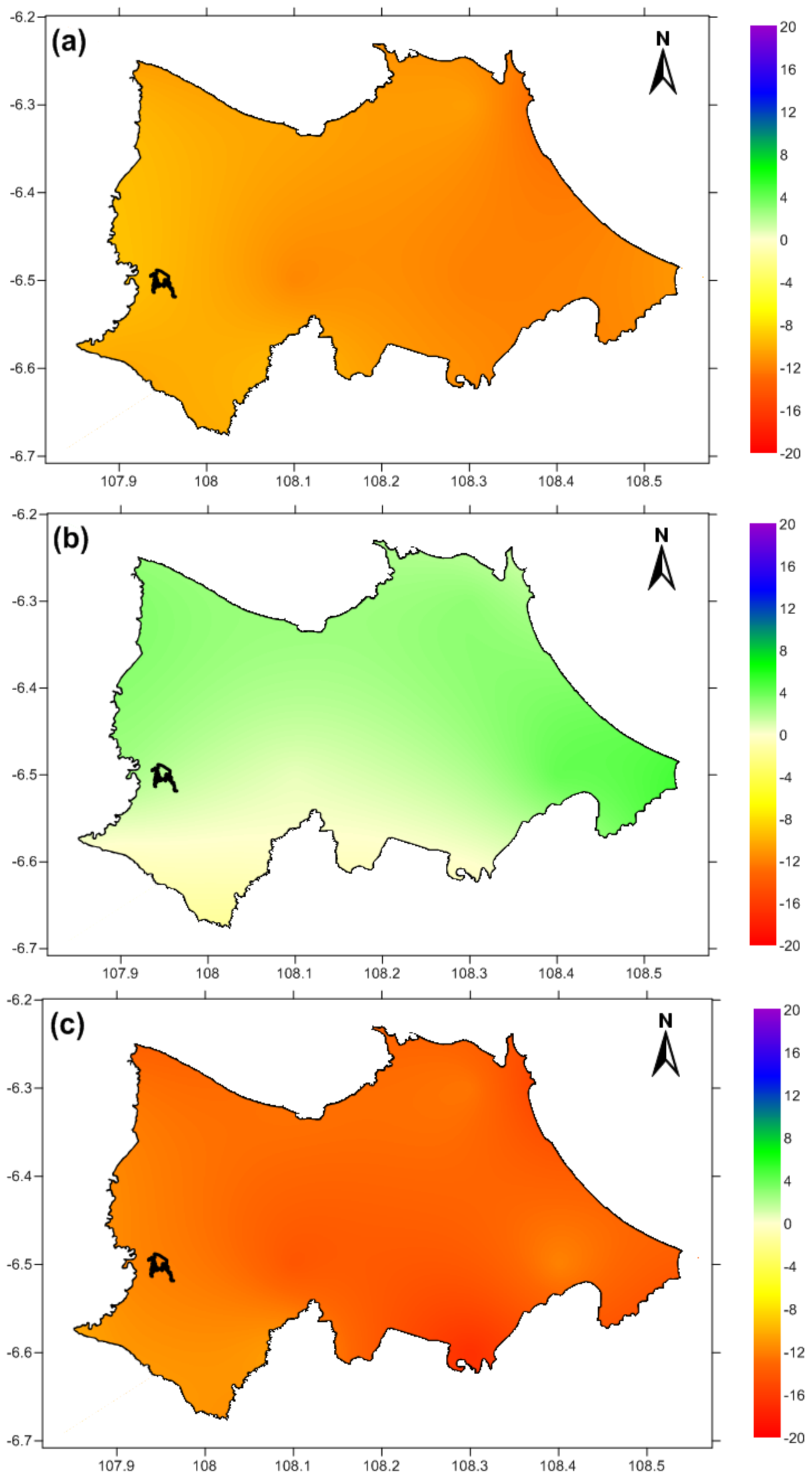

Gambar 3. Proyeksi perubahan curah hujan (dalam persen) berdasarkan skenario SRES A1B: (a) periode tahun 2021-2040, (b) periode tahun 2041-2060, dan (c) periode tahun 2061-2080, relatif terhadap curah hujan model periode tahun 1980-1999. Gradasi warna menggambarkan bahwa semakin merah wilayah tersebut akan semakin kering. 


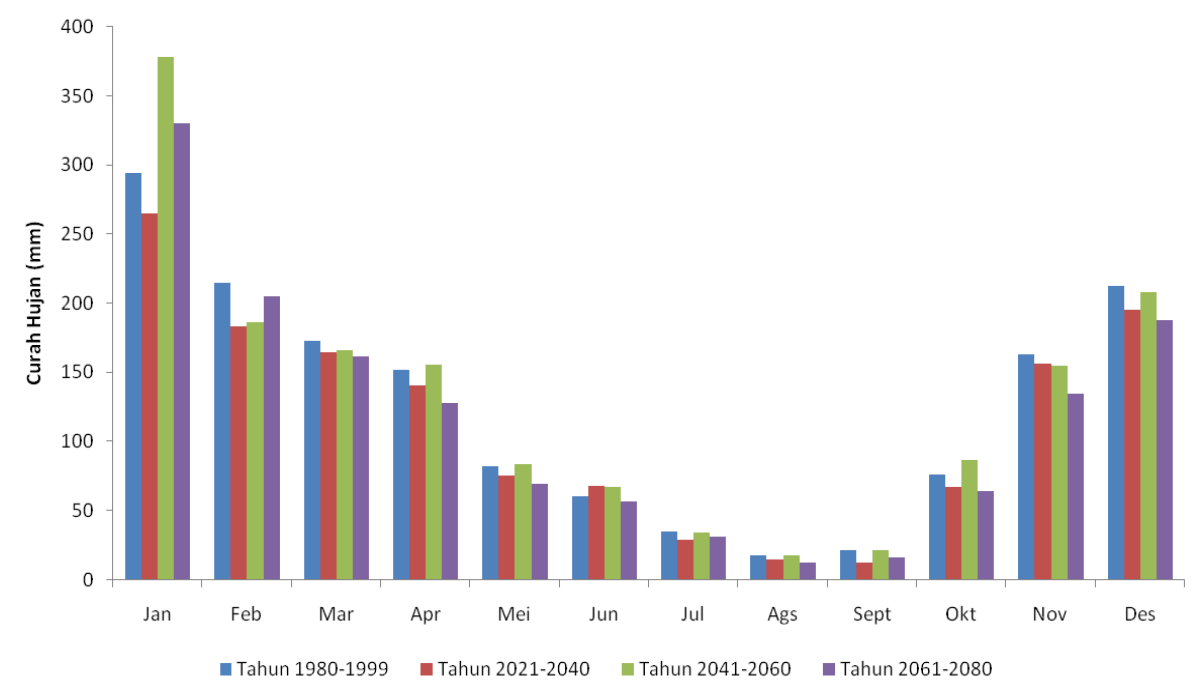

Gambar 4. Pola distribusi curah hujan rata-rata bulanan periode baseline dan proyeksi berdasarkan hasil keluaran model RegCM3.

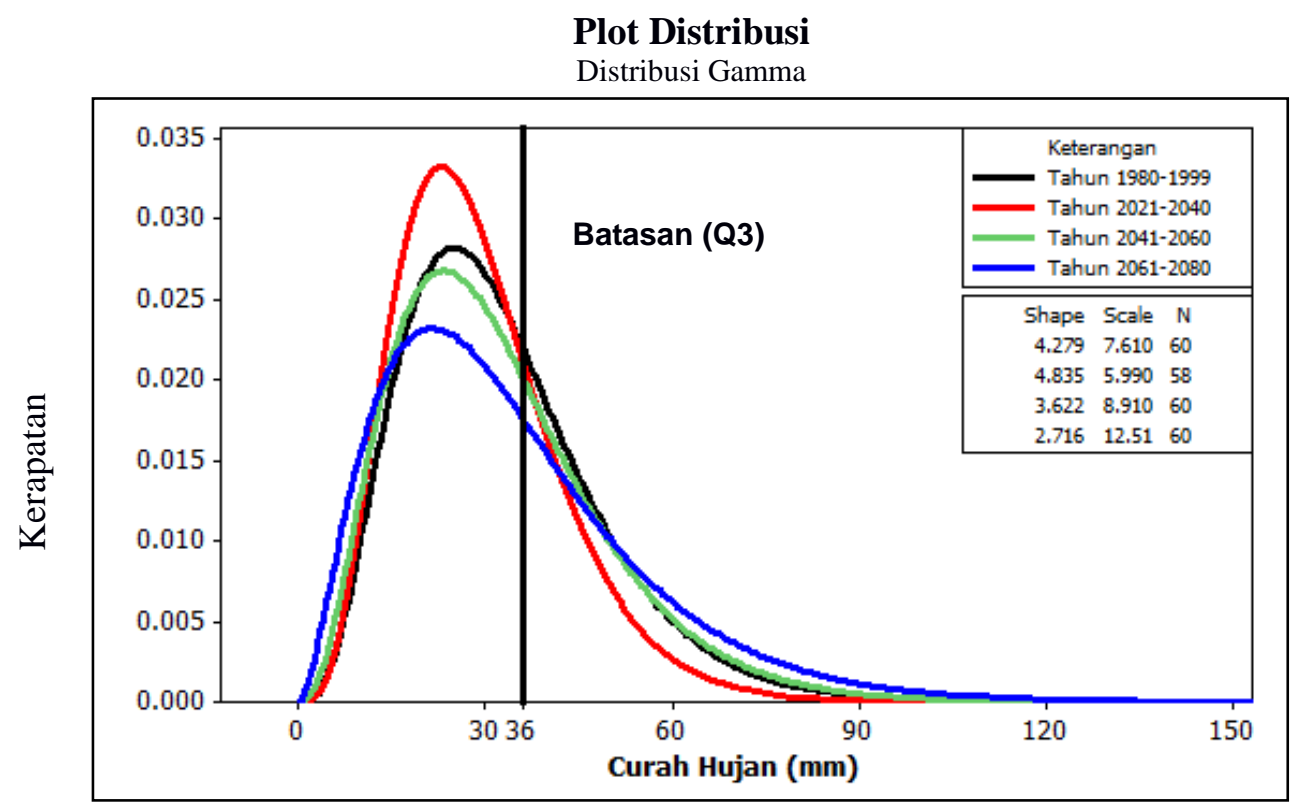

Gambar 5. Peluang terlampaui curah hujan maksimum (ekstrim) harian dengan batasan (threshold) berdasarkan nilai Quartile $3(36 \mathrm{~mm})$.

Perubahan curah hujan di masa mendatang juga berdampak pada kondisi hidrologi suatu wilayah. Li et al. (2010) mengindikasikan bahwa peningkatan $1 \%$ curah hujan dapat meningkatkan 1 hingga $4 \%$ limpasan permukaan. Kondisi tersebut tentu dapat menyebabkan terjadinya banjir pada musim penghujan dan kekeringan pada musim kemarau. Oleh karena itu, diperlukan adaptasi untuk mengatasi dan meminimalkan resiko yang mungkin terjadi. Dasanto dan Impron (2008) menyatakan bahwa waduk dapat dimanfaatkan sebagai tempat penyimpanan air hujan yang berlebih. Waduk dapat difungsikan sebagai penyedia kebutuhan air irigasi, rumah tangga/domestik dan suplai listrik melalui PLTA.

\section{Analisis Hujan Ekstrim}

Perubahan curah hujan di masa mendatang selain berpengaruh terhadap tinggi hujan, juga akan berpengaruh terhadap distribusi curah hujan maksimum (CHmax). Curah hujan maksimum dapat dikatakan sebagai curah hujan ekstrim karena curah hujan tersebut dapat menjadi penyebab terjadinya banjir di musim penghujan. Pada analisis ini, kejadian hujan ekstrim yang didasarkan pada curah hujan maksimum harian dilakukan hanya pada bulan Desember-Januari-Februari (DJF) yang merupakan periode puncak musim hujan dalam setahun.

Distribusi curah hujan ekstrim didasarkan pada distribusi peluang dengan menggunakan sebaran gamma. Berdasarkan distribusi tersebut kita dapat 
melihat peluang terlampaui sesuai batasan (threshold) curah hujan ekstrim yang kita definisikan. Batasan (threshold) dibuat sebagai acuan untuk memperoleh besar peluang curah hujan ekstrim. Batasan (threshold) curah hujan ekstrim yang digunakan dalam kajian ini adalah berdasarkan besar nilai kuartil 3 (Q3) dari data curah hujan maksimum observasi (tahun 1980-1999) pada bulan Desember-Januari-Februari (DJF). Dari hasil analisis diperoleh nilai Q3 adalah $36 \mathrm{~mm}$, yang artinya bahwa curah hujan harian pada bulan DesmberJanuari-Februari yang melebihi nilai $36 \mathrm{~mm}$ dapat dikatakan sebagai curah hujan ekstrim.

Gambar 5 merupakan distribusi peluang curah hujan maksimum harian berdasarkan sebaran gamma. Dari gambar tersebut dapat dilihat bahwa peluang terlampaui curah hujan ekstrim pada periode proyeksi tidak mengalami perubahan yang besar dibandingkan periode baseline. Periode tahun 2021-2040 mengalami penurunan peluang sebesar 0,096 dan pada periode tahun 2041-2060 mengalami penurunan peluang sebesar 0,005 . Periode tahun 2061-2080 merupakan periode yang mengalami peningkatan peluang curah hujan ekstrim, dimana peningkatannya hanya 0,027 . Besar peluang curah hujan ekstrim tersebut mengindikasikan bahwa kondisi curah hujan harian di masa mendatang tidak banyak yang melebihi nilai $36 \mathrm{~mm}$, sehingga ancaman terjadinya banjir pada lahan pertanian dapat dihindari.

\section{KESIMPULAN}

Curah hujan menjadi unsur iklim yang cukup rentan mengalami perubahan akibat perubahan iklim. Kondisi tersebut membuat curah hujan menjadi salah satu unsur yang banyak dianalisis terkait perubahan iklim. Analisis curah hujan masa depan didasarkan pada metode dynamical downscaling menggunakan model RegCM3. Metode tersebut digunakan untuk memperoleh informasi curah hujan yang lebih detail untuk analisis secara lokal/regional dari luaran Global Climate Model (GCM). Berdasarkan hasil analisis menggunakan model RegCM3 dengan skenario perubahan emisi SRES A1B yang menggambarkan keseimbangan penggunaan bahan bakar fosil dan non-fosil di masa mendatang, curah hujan di Kabupaten Indramayu cenderung akan mengalami penurunan dengan periode tahun 2061-2080 merupakan periode dengan penurunan curah hujan terbesar. Peluang hujan ekstrim harian di Kabupaten Indramayu di masa mendatang cenderung tetap, karena perubahan yang terjadi tidak begitu besar.

\section{DAFTAR PUSTAKA}

Alfyanti R. 2011. Pemanfaatan Luaran RegCM3 untuk Kajian Dampak Perubahan Iklim terhadap Perubahan Waktu dan Pola Tanam Padi di Jawa Barat [Skripsi]. Institut Pertanian Bogor, FMIPA. Bogor.

Asdak C. 1995. Hidrologi dan Pengelolaan Daerah Aliran Sungai. Gadjah Mada University Press. Yogyakarta.

Dasanto B.D. dan Impron. 2008. Upaya Adaptasi Sektor Sumberdaya Air dan Pertanian Untuk Mengurangi Dampak Peubahan Iklim. Makalah Rapat Kerja ELSDA. Jakarta.

Dickinson R.E., Henderson-Sellers A. and Kennedy P.J. 1993. Biosphere-atmosphere transfer scheme (BATS) version $1 \mathrm{e}$ as coupled to the ncar community climate model. Tech. rep. National Center for Atmospheric Research.

Emanuel K.A. 1991. A scheme for representing cumulus convection in large-scale models. J Atmos Sci. 48(21):2313-2329.

Emanuel K.A. and Zivkovic-Rothman M. 1999. Development and evaluation of a convection scheme for use in climate models. J Atmos Sci. 56: 1766-1782.

Faqih A., Buono A. and Boer R. 2011. Current and future climate, ENSO impacts and extreme weather events. The Assessment of Economics of Climate Change in the Pacific (Final Report). Asian Development Bank (ADB) No. S21321 TA - 7394 (REG): Strengthening the Capacity of Pacific Developing Member Countries to Respond to Climate Change. CCROM-SEAP, IPB. Chapter 2, Page II-7.

Giorgi F., Hewitson B., Christensen J., Hulme M., Von Storch H., Whetton P., Jones R., Mearns L. and Fu C. 2001. Regional climate information Evaluation and projections. In Climate Change 2001. The Scientific Basis, Contribution of Working Group I to the Third Assessment Report of the Intergovernmental Panel on Climate Change. JT Houghton, Y Ding, DJ Griggs, M Noguer, PJ van der Linden, X Dai, K Maskell dan CA Johnson (eds.). Cambridge University Press. Cambridge. UK. pp. 583-638.

Hay L.E. and Clark M.P. 2003. Use of statistically and dynamically downscaled atmospheric model output for hydrologic simulations in three mountainous basins in the western United States. $J$ Hydrology. 282:56-75.

Holtslag A.A.M., de Bruijn E.I.F. and Pan H.-L. 1990. A high resolution air mass transformation model for short-range weather forecasting. Mon Wea Rev. 118:1561-1575.

Hulme M. and Sheard N. 1999. Climate Change Scenarios for Indonesia. Leaflet CRU and WWF. Climatic Research Unit. UEA, Norwich,UK.

[IPCC] Intergovernmental Panel on Climate Change. 2000. Emission Scenario. A Special Report of Working Group III of the IPCC. Intergovernmental Panel on Climate Change. Cambridge University Press. 
Kurniawan E., Herizal dan Budi S. 2009. Proyeksi Perubahan Iklim Berdasarkan Skenario IPCC SRES dengan Menggunakan Model AOGCM CCSR/NIES. Buletin Meteorologi Klimatologi dan Geofisika. 5(2).

Li Z., Liu W.Z., Zhang X.C. and Zheng F.L. 2010. Assessing the site-specific impacts of climate change on hydrology. Soil erosion and crop yield in the loess Planteau of China. Springer-Verlag. China.

Park E.H., Hong S.Y. and Kang H.S. 2008. Characteristics of an East-Asian summer monsoon climatology simulated by the RegCM3. Departement of Atmospheric Sciences, Global Environment Laboratory, Yonsei University, Seoul, Korea.
Sarah D. dan Tohari A. 2009. Pemodelan Perubahan Iklim Daerah Kabupaten Sukabumi Menggunakan MAGICC/SCENGEN. Prosiding Pemaparan Hasil Penelitian Puslit Geoteknologi. LIPI. Bandung.

Spak S., Holloway T., Lynn B. and Goldberg R. 2007. A comparison of statistical and dynamical downscaling for surface temperature in North America. $J$ Geophys Res. 112:D08101. doi:10.1029/2005JD006712.

Susandi A., Indriani H., Mamad T. dan Irma N. 2008. Dampak perubahan iklim terhadap ketinggian muka laut di wilayah Banjarmasin. J Ekon Ling. 12(2). 